\title{
A Comparative Study on the Effect of Organic and Inorganic Fertilizers on Agronomic Performance of Faba Bean (Vicia faba L.) and Pea (Pisum sativum L.)
}

\author{
Bhaskarrao Chinthapalli", Dagne Tafa Dibar, D. S. Vijaya Chitra, Melaku Bedaso Leta \\ Department of Biology, College of Natural Sciences, Arba Minch University, Arba Minch, P.O. Box No. 21, Ethiopia \\ Email address: \\ chinthapalli.bhaskar@amu.edu.et (B. Chinthapalli)
}

\section{To cite this article:}

Bhaskarrao Chinthapalli, Dagne Tafa Dibar, D. S. Vijaya Chitra, Melaku Bedaso Leta. A Comparative Study on the Effect of Organic and Inorganic Fertilizers on Agronomic Performance of Faba Bean (Vicia faba L.) and Pea (Pisum sativum L.). Agriculture, Forestry and Fisheries. Vol. 4, No. 6, 2015, pp. 263-268. doi: 10.11648/j.aff.20150406.15

\begin{abstract}
The study was conducted to observe the comparative effect of organic fertilizer (cow dung) and inorganic fertilizers like urea and potassium chloride on the growth, biomass and biochemical parameters of two legumes of pea (Pisum sativum) and faba bean (Vicia faba). Experiments were done using two plant species of legume family. Organic fertilizer like cow dung (15t/ha) and inorganic fertilizer was applied at rate of urea (120kg/ha) and potassium chloride (125kg/ha). The application of cow dung at 15t/ha showed significant growth over the inorganic fertilizer urea and potassium chloride in terms of germination percentage, fresh weight and dry weight, plant height, shoot length, and root length as well as number of leaves in both the legume plants. Similarly, biochemical parameters have also shown significant differences from organic fertilizer over the inorganic fertilizers and control. Thus our study provides the evidence for using organic fertilizer like cow dung by farmers to have better yield to produce quality grains as cow dung is easy available, environmentally safe and cost effective in pea and faba bean plants.
\end{abstract}

Keywords: Growth, Cow Dung, Urea, Potassium Chloride, Biomass, Pea (Pisum sativum), Faba Bean (Vicia faba)

\section{Introduction}

Less soil fertility is considered to be one of the most important constraints on improved agricultural production [1]. Fertilizers are used to improve fertility and are indispensable for sustained food production, but excessive use of mineral fertilizers has aroused environmental concerns. Organic fertilizers coming from fermented and decomposed organic materials are generally nutritious and safe. Microbial fertilizers are apparently environment friendly, low cost and non-bulky agricultural inputs which play a significant role in plant nutrition as a supplementary and complementary factor to mineral nutrition [2]. Therefore fertilizer and plant nutrition research should establish a workable relation between environment preservation and fertilizers [3].

Legumes are an important source of protein for humans and live stock. They provide nutritionally rich crop residues for animal feed and also humans and play a key role in maintaining the productivity of soil. They also play a unique role due to their ability of fixing atmospheric nitrogen [4]. In Ethiopia, faba bean (Vicia faba L.) and pea (Pisum sativum L.) are mainly grown for human consumption and one of the most important food crops [5]

Fertilizer is very important for crop growth and productivity. One example, of fertilizer is cow dung which is obtained from cow, which is environmental friendly, is easily used and compared with chemical fertilizer which increases the environmental problems. Organic fertilizers are used easily from locality products and livestock wastes and cost effective than chemical fertilizer [6].

The most useful factor is nutrient supply; organic farming is one of the fastest growing sectors of the agriculture worldwide. Its main objective of to create a balance between inter connected system of the soil organism, plants, animals and humans [7]. The choices of suitable forms of fertilizer of the crop growth of the plant are governed by local, natural condition and variation in soil and climate with regard to their suitability for crops cultivation [8]. Numerous test and experience have shown that farm yard manure with its long time effective nutrients 
is an ideal fertilizer for crop growth [9].

According to [8], fertilizers are resource of plant nutrient that can be added to supplement soil natural fertility. Crop plants have great demand for nitrogen, phosphorous and potassium as a whole main significance in maintenance of normal physiological function of the cell. In similar way according to [10] lack of nitrogen can result in slow growth and poor yield, but excess nitrogen results in deleted maturity and low quality of leaf, phosphorus deficient crop plants are turned abnormally dark green and late maturing, excessive phosphorus shorten leaf, burn duration, lack potassium as common cause of low quality, the source of potassium also important. Additional studies on corn crop plants on cow dung mixed soil is a good source of different plant nutrients particularly N.P.Ks [11]

The present study was conducted to compare the effects of organic and inorganic fertilizers on two legume species of faba bean and pea to determine the germination, seedling growth and biomass of crop plants and also to compare the physical characters or growth parameters with biochemical parameters treated with organic and inorganic chemical fertilizers.

\section{Materials and Methods}

\subsection{Experimental Site}

Arba Minch is found in SNNPRS. It located at $30^{\circ} 56^{\prime} \mathrm{N}$ of the equator and $37^{\circ} 44^{\prime} \mathrm{E}$ with surface area of 2184 hectares of land with altitude ranged from 1200-1400 masl with average temperature $30.6^{\circ} \mathrm{C}$, annual rainfall $575 \mathrm{~mm}$, situated in 505 $\mathrm{km}$ away towards south of Addis Ababa in Great Rift Valley of lake Abaya and Chamo. The study was conducted in Abaya Campus, sikela $5 \mathrm{Km}$ away from Arba Minch University.

\subsection{Experimental Design and Layout}

The experiment was laid out in a randomized complete block design was used with three replicates. Faba bean and pea seeds were procured from the Arba Minch Agriculture College. The treatments of organic (cow dung) fertilizer and inorganic fertilizer like Urea (120kg/ha having $46 \% \mathrm{~N})$ and Potassium Chloride $\left(125 \mathrm{~kg} /\right.$ ha having $\left.60 \% \mathrm{~K}_{2} \mathrm{O}\right)$ calculated according to the application of fertilizer per hectare soil and added to the prepared plots with the bean and pea seeds separately [12]. The cow dung that was used for these experiments were collected from the farm yard. The cow dung collected was subjected to different management practices like mixing thoroughly with a shovel with the aim of reconciling it and applied 15t/ha [13].

The size of the experimental plots was $3.2 \mathrm{~m} \times 4.5 \mathrm{~m}$ $\left(14.4 \mathrm{~m}^{2}\right)$ with $1.3 \mathrm{~m}$ spacing between blocks and $0.8 \mathrm{~m}$ between plots. Each plot had 7 rows. The inter-row and intrarow spacing were respectively $0.7 \mathrm{~m}$ and $0.3 \mathrm{~m}$. The central five rows were used for data collection. All agronomic practices such as land preparation and weeding were performed as per the local farmers' practices.

\subsection{Physical Parameters}

Measurements of percentage of germination, shoot length, root length, shoot Fresh weight and dry weight and root fresh weight and dry weight of both legume plant species were taken at 35 days after-planting (vigorous vegetative growth).

\subsection{Biochemical Parameters}

Leaf samples from two plant species in the net rows were harvested for chlorophyll estimation following the methods [14-15], in which $100 \mathrm{mg}$ fresh leaf was crushed in $20 \mathrm{ml}$ of $80 \%$ acetone and the extract centrifuged for $10 \mathrm{~min}$ at 1000 $\mathrm{rpm}$. Absorbance of the supernatant was recorded at 645 and $663 \mathrm{~nm}$ in a UV-Spectrophotometer (Hitachi). Chlorophyll content (expressed as $\mathrm{mg} / \mathrm{g}-1$ of each sample) was estimated according to [15] as follow:

Chlorophyll a $(\mathrm{mg} / \mathrm{g}-1)=12.7(\mathrm{~A} 663)-2.69(\mathrm{~A} 645) \mathrm{x}$ VW

Chlorophyll b $(\mathrm{mg} / \mathrm{g}-1)=22.9(\mathrm{~A} 645)-4.86(\mathrm{~A} 663) \mathrm{x}$ VW

Total Chlorophyll $\mathrm{t}(\mathrm{mg} / \mathrm{g}-1)=[20.2(\mathrm{~A} 645)-8.02(\mathrm{~A} 663)$ $\mathrm{x} \mathrm{VW]/1000}$

Where $\mathrm{A}=$ absorbance at the given wavelength, $\mathrm{W}=$ weight of fresh leaf sample, $V=$ final volume of chlorophyll solution.

The total soluble protein was estimated by using either Bradford's reagent Folin-Phenol reagent [16], with bovine serum albumin as the standard. Amino acid content of seedlings was measured by the following method [17]. Sugars were estimated by the standard method of [18].

\subsection{Replications and Statistical Analysis}

All experiments were repeated 3 to 5 times on different days. The average values $\pm \mathrm{SE}$ are presented. Statistical analysis of the data was done using the software Sigma plot (version 10.0).

\section{Results}

Agronomic performance of both legume plant species of faba bean (Vicia faba L.) and pea (Pisum sativum L.) were significantly influenced by the treatments of organic (cow dung) and inorganic fertilizer (urea and potassium chloride) over the control.

\subsection{Percentage of Germination}

The average cumulative germination percentage with organic and inorganic treatments was compared with control of bean and pea and is summarized (Figure 1 (a)). It was clearly observed that organic fertilizer (cow dung) showed high frequency of $92-96 \%$ germination when compared with inorganic fertilizer (urea and potassium chloride) of (80$86 \%$ ) after 35 days of germination over the control of only $82 \%$ in faba bean and pea. 


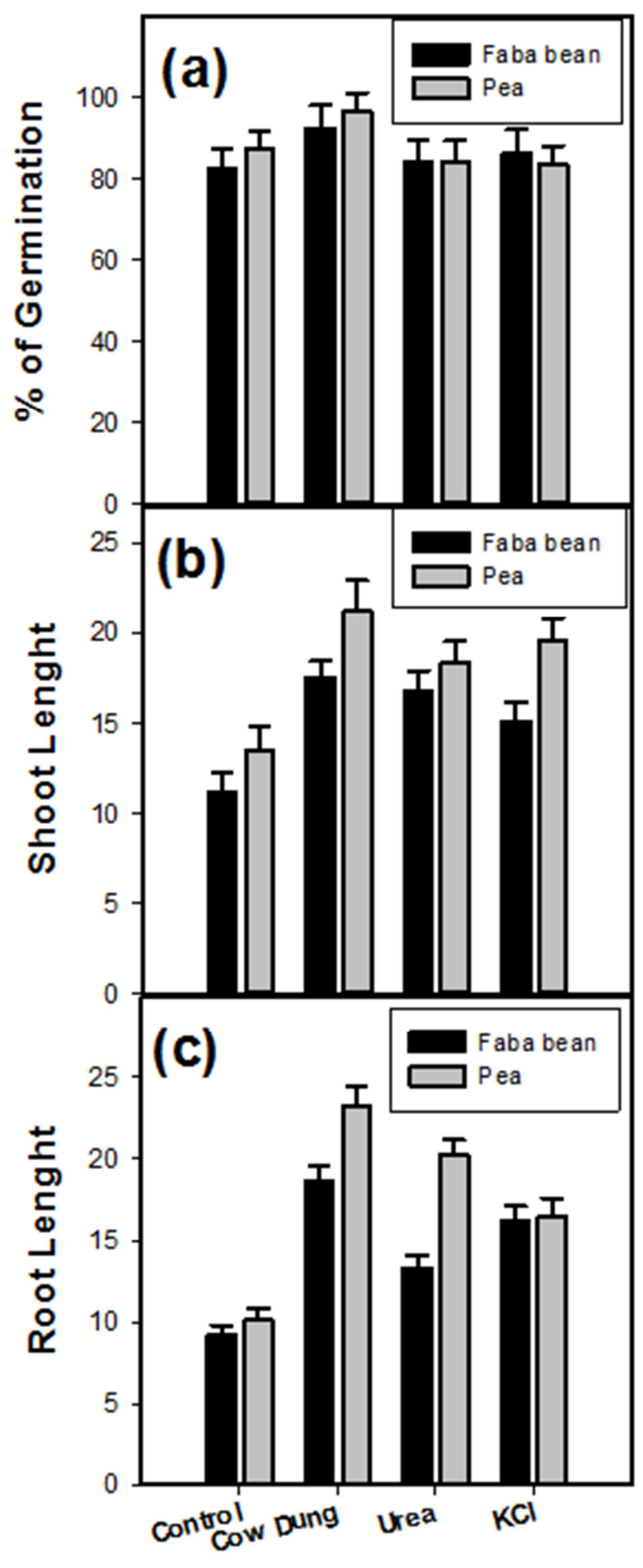

\section{Treatment}

Figure 1. Effect of organic and inorganic fertilizers on faba bean and pea plants (a) \% of germination (b) shoot length (c) root length. The experiments were done on at least three different days and the average values are $\pm S E$ represented.

\subsection{Shoot Length and Root Length}

Further experiments was designed to determine the changes particularly the mean shoot length and root length in the seedlings of 35 days old faba bean and pea with different treatments of organic, inorganic fertilizers over the control (Figure 1 ( $b$ and $c)$ ). The seedlings were pulled from the soil without the damage of root and measured with measuring scale. The length of the shoot increased in case of faba bean seedlings from organic fertilizers over inorganic fertilizers and control respectively. In the control the length of the shoot was observed to be the least. Similar observations are seen in the pea seedlings with increase in shoot length from organic fertilizer over inorganic fertilizers and control.

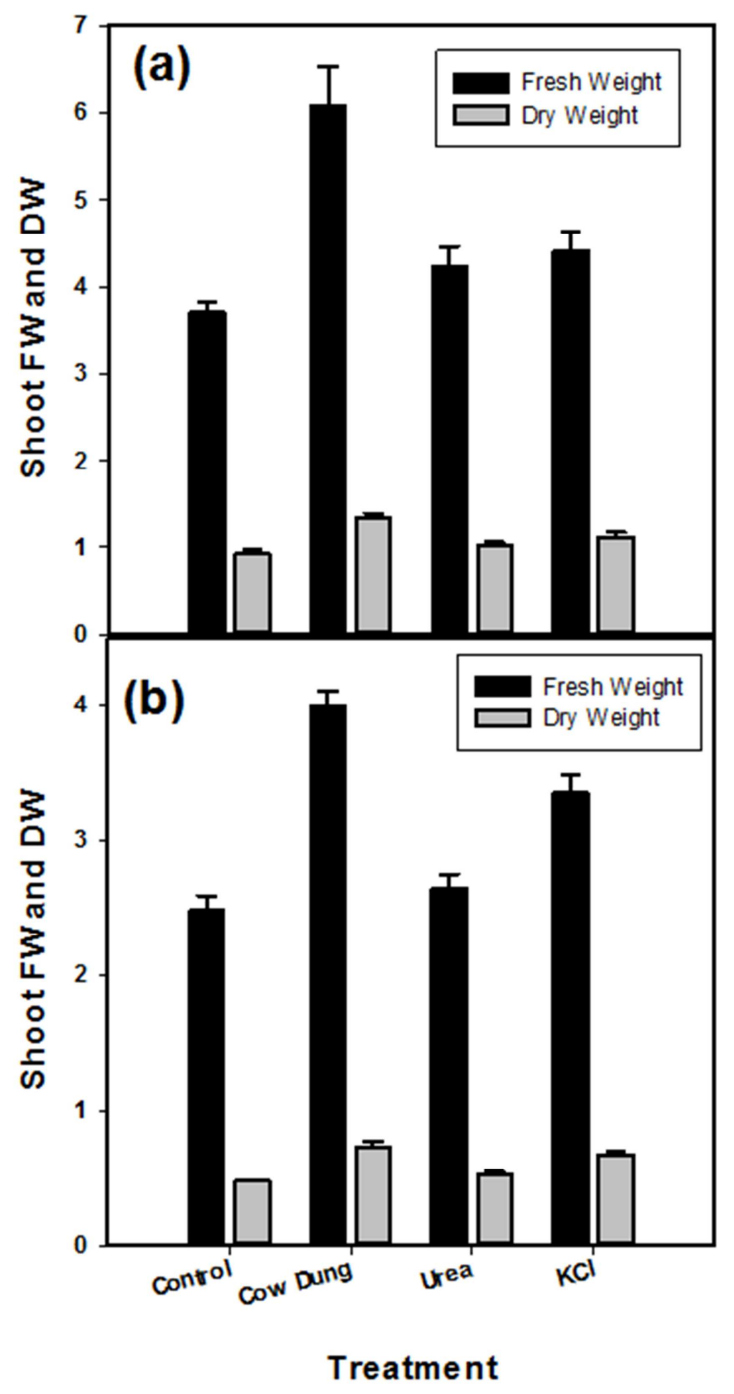

Figure 2. Effect of organic and inorganic fertilizers of (a) shoot fresh weight and dry weight of faba bean (b) shoot fresh weight and dry weight of pea. The experiments were done on at least three different days and the average values are $\pm S E$ represented.

\subsection{Biomass}

There was a marked difference of fresh weight and dry weight biomass between organic and inorganic fertilizers over control in both faba bean and pea plants. The average values of fresh weight and dry weight biomass of faba bean and pea plants treated with organic are higher than those with inorganic and control (Figure 2 ( $\mathrm{a}$ and $\mathrm{b}$ ) and Figure 3 (a and b). There is no much significant difference between bean and pea seedlings in fresh weight biomass compared to that of dry weight biomass, where as significant difference was observed treated with organic fertilizer. 


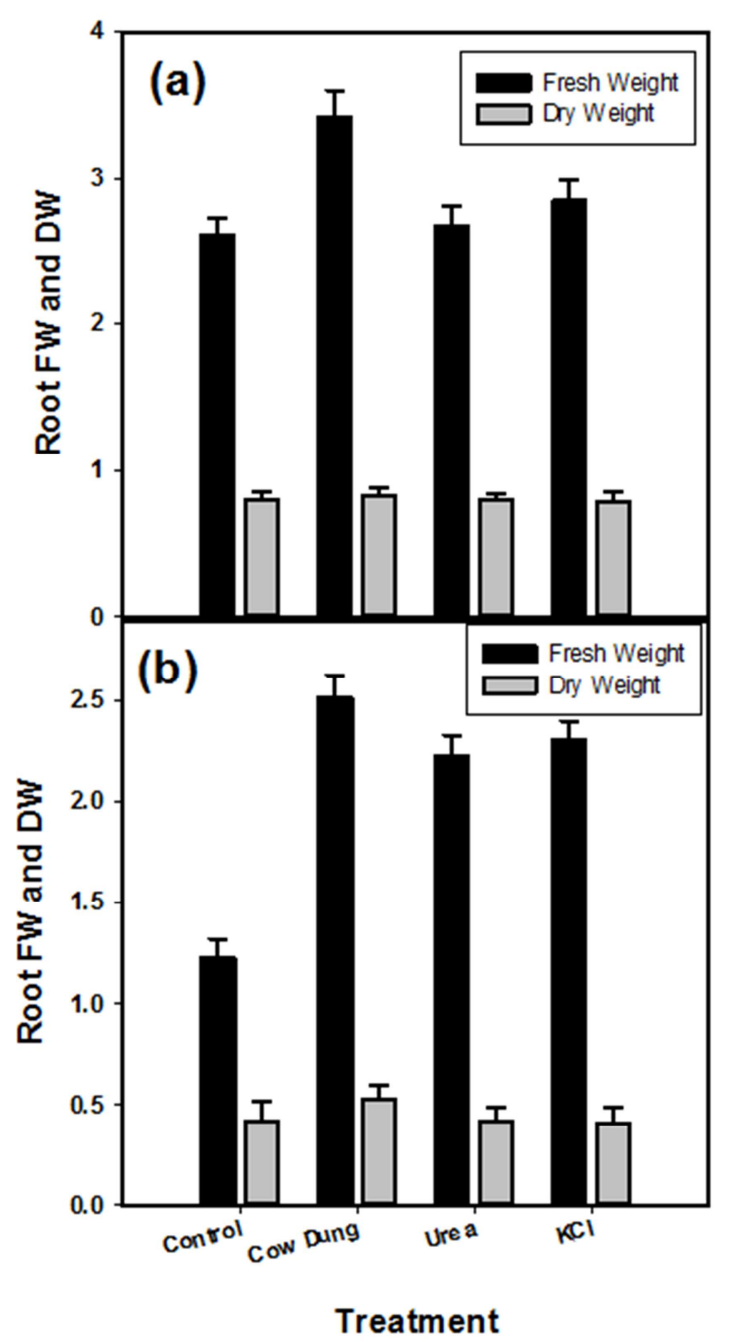

Figure 3. Effect of organic and inorganic fertilizers of (A) root fresh weight and dry weight of faba bean (B) root fresh weight and dry weight of pea. The experiments were done on at least three different days and the average values are $\pm S E$ represented.

\subsection{Chlorophyll Estimation of Bean and Pea Seedlings}

Significant difference was observed in both faba bean and pea plants grown in soils treated with organic and inorganic over the control (Table 1). The highest content of chlorophyll-a, chlorophyll-b, total chlorophyll were recorded in both faba bean and pea plants grown in soil treated with cow dung over the inorganic fertilizers like urea and potassium chloride. Similarly, the lowest chlorophyll-a, chlorophyll-b, total chlorophyll were recorded in both faba bean and pea grown without fertilizers (control). Indication of high levels of chlorophyll a, b and total chlorophyll content is a result of effective photosynthetic and metabolic activity. The disappearance of chlorophyll is the one of the most prominent phenomenon of an advanced age and rate of chlorophyll degradation.

\subsection{Total Sugars, Soluble Protein and Amino Acids}

Increased levels of total sugars were seen in the plants grown in soils treated with cow dung over control. Lowest levels of total sugars were observed in urea and potassium chloride. Similarly, total soluble proteins and amino acids were high in case of organic fertilizer cow dung over the inorganic fertilizers like urea and potassium chloride and control (Table 2).

\section{Discussion}

In present study, all the treatments with organic and inorganic fertilizers recorded higher germination percentage compared to control samples. The maximum, seed germination was observed in organic fertilizer (cow dung) treatment (Figure $1(\mathrm{a})$ ). These results are almost similarly agreed with the findings of [19] in Albizia and [20] in Triticum. Improved seed germination might be attributed to the role of some important microorganism which influence in enhancing the easy availability of nitrogen, phosphorus and potassium in the soil and making available to the germinating seed with consequent enhancement in the cell metabolic activity resulting in higher germination [21-22, 8]. According to [23] the nutrients present in organic fertilizers can be released only when its decomposition takes a long period of time.

Table 1. Effect of organic and inorganic fertilizers on the chlorophyll a, chlorophyll b and total chlorophyll in different plant species of faba bean and pea.

\begin{tabular}{lllllll}
\hline \multirow{2}{*}{ Treatment } & Faba bean & & & Pea & & \\
\cline { 2 - 7 } & $\begin{array}{l}\text { Chlorophyll a } \\
(\mathbf{m g} / \mathbf{g} \text { FW) }\end{array}$ & $\begin{array}{l}\text { Chlorophyll b } \\
(\mathbf{m g} / \mathbf{g} \text { FW) }\end{array}$ & $\begin{array}{l}\text { Total chlorophyll } \\
(\mathbf{m g} / \mathbf{g} \text { FW) }\end{array}$ & $\begin{array}{l}\text { Chlorophyll a } \\
(\mathbf{m g} / \mathbf{g} \text { FW) }\end{array}$ & $\begin{array}{l}\text { Chlorophyll b } \\
(\mathbf{m g} / \mathbf{g} \text { FW) }\end{array}$ & $\begin{array}{l}\text { Total chlorophyll } \\
\text { (mg/g FW) }\end{array}$ \\
\hline Control & $1.461 \pm 0.041$ & $0.661 \pm 0.012$ & $1.792 \pm 0.045$ & $0.871 \pm 0.015$ & $0.422 \pm 0.009$ & $1.476 \pm 0.068$ \\
Cow dung & $1.512 \pm 0.061$ & $0.837 \pm 0.011$ & $2.434 \pm 0.051$ & $1.423 \pm 0.068$ & $0.531 \pm 0.010$ & $1.784 \pm 0.052$ \\
Urea & $1.312 \pm 0.075$ & $0.804 \pm 0.022$ & $2.237 \pm 0.052$ & $1.272 \pm 0.054$ & $0.417 \pm 0.008$ & $1.433 \pm 0.054$ \\
Potassium chloride & $1.437 \pm 0.052$ & $0.786 \pm 0.019$ & $2.146 \pm 0.041$ & $1.326 \pm 0.061$ & $0.395 \pm 0.005$ & $1.571 \pm 0.046$ \\
\hline
\end{tabular}

Table 2. Effect of organic and inorganic fertilizers on the total sugars, soluble proteins and amino acids in different plant species of faba bean and pea.

\begin{tabular}{|c|c|c|c|c|c|c|}
\hline \multirow[b]{2}{*}{ Treatment } & \multicolumn{3}{|l|}{ Faba bean } & \multicolumn{3}{|l|}{ Pea } \\
\hline & $\begin{array}{l}\begin{array}{l}\text { Total Sugars } \\
(\mathrm{mg} / \mathrm{g} \text { FW) }\end{array} \\
\end{array}$ & $\begin{array}{l}\begin{array}{l}\text { Soluble proteins } \\
(\mathrm{mg} / \mathrm{g} \text { FW) }\end{array} \\
\end{array}$ & $\begin{array}{l}\text { Amino acids } \\
(\mathrm{mg} / \mathrm{g} \text { FW) }\end{array}$ & $\begin{array}{l}\begin{array}{l}\text { Total Sugars } \\
(\mathrm{mg} / \mathrm{g} \text { FW) }\end{array} \\
\end{array}$ & $\begin{array}{l}\text { Soluble proteins } \\
(\mathrm{mg} / \mathrm{g} \text { FW) }\end{array}$ & $\begin{array}{l}\begin{array}{l}\text { Amino acids } \\
(\mathrm{mg} / \mathrm{g} \text { FW) }\end{array} \\
\end{array}$ \\
\hline Control & $4.427 \pm 0.097$ & $2.621 \pm 0.042$ & $1.512 \pm 0.041$ & $4.321 \pm 0.081$ & $2.423 \pm 0.035$ & $1.325 \pm 0.021$ \\
\hline Cow dung & $4.921 \pm 0.073$ & $3.101 \pm 0.051$ & $1.684 \pm 0.032$ & $4.634 \pm 0.062$ & $3.011 \pm 0.043$ & $1.412 \pm 0.024$ \\
\hline Urea & $4.312 \pm 0.062$ & $2.912 \pm 0.047$ & $1.574 \pm 0.037$ & $4.199 \pm 0.057$ & $2.721 \pm 0.032$ & $1.401 \pm 0.022$ \\
\hline Potassium chloride & $4.321 \pm 0.075$ & $3.011 \pm 0.053$ & $1.594 \pm 0.023$ & $4.152 \pm 0.055$ & $2.812 \pm 0.025$ & $1.392 \pm 0.027$ \\
\hline
\end{tabular}


Effect of organic and inorganic fertilizers on shoot length and root length, of faba bean and pea were significant. The parameters showed best performance in organic fertilizer over the inorganic fertilizers, and the lowest were in control (Figure 1 (b and $\mathrm{c})$ ). Compared to shoot length, the root length had shown a drastic increase in both faba bean and pea seedlings treated with organic over inorganic fertilizers and control. Similar observations were also made according to [24] using biomeal as organic fertilizer in crop plant like carrot. According to [10], increase in N.P.K led to a significant increase in plant height and grain yield. Organic fertilizer cow dung is primarily responsible for the increase in biomass of both faba bean and pea plants. Among nitrogen, phosphorus and potassium, the essential nutrient required by crop plants, Nitrogen in the most commonly deficient in tropical soil [25], which is much available through the decomposition of organic matter.

It is also found (Figure 2 ( $a$ and $b$ ) and Figure 3 ( $a$ and $b$ )) that application of cow dung and inorganic fertilizers like urea and potassium chloride significantly increased fresh and dry weight of both shoot and root in faba bean and pea. On the other hand, the lowest fresh and dry weight of shoot and root were seen from control, respectively. These results are consistent with the findings of [26], they reported that vermin compost, neem cake and FYM (farm yard manure) in carrot. A similar observation was also reported by [27] from a study on the effect of few eco-friendly manures on the growth attributes of carrot and [28] from agricultural waste composts. The results obtained from the present study indicate that the application of cow dung would be sufficient enough for proper growth shoot and root of faba bean and pea plant respectively.

The effect of cow dung and inorganic fertilizers like urea and potassium chloride on photosynthetic pigments of faba bean and pea was presented in Table 1 . The highest content of chlorophyll a $(1.512 \pm 0.061 \mathrm{mg} / \mathrm{g}$ fr. wt. $)$, chlorophyll b $(0.837 \pm 0.011 \mathrm{mg} / \mathrm{g}$ fr. wt.) and total chlorophyll $(2.434 \pm$ $0.051 \mathrm{mg} / \mathrm{g}$ fr. wt.) were recorded in faba bean over pea grown in soil treated with cow dung and inorganic fertilizers. Similarly, the lower levels chlorophyll a, chlorophyll b, and total chlorophyll content (Table 1) were recorded without fertilizers (control). The indication of better photosynthetic and cell metabolic activity are mainly due to chlorophyll $\mathrm{a}, \mathrm{b}$ and total chlorophyll content. The gradual ceasing of chlorophyll is the one of the most prominent phenomenon of an advanced age and rate of chlorophyll degradation [29-31]. The presence or absence of chlorophyll in plant greatly affects the production of secondary metabolites viz., proteins, glycosides, tannins, carotenoids etc. and other essential plant constituents [32]. It has been proved that chlorophyll play an important role in the ATP generation and prevention of essential plant constituents [33]. Similarly, the higher sugar, proteins and amino acid content of seedling was observed at application of organic fertilizer (cow dung) over the inorganic fertilizers and control (Table 2). However, similar results were observed that soluble sugar content was higher under organic fertilization compared to inorganic fertilization. This drift may be due to the lesser starch content when soils treated with without fertilizer and inorganic fertilizers which implies the starch metabolism and poor translocation of sugar to growing part [34].

According for our findings, it would be liable to recommend the use of organic fertilizers cow dung for farmers seeking a better yield for optimum growth of legume plant species. However, inorganic fertilizers, also help in growth and yield of legume species. The reason for this is noteworthiness the cow-dung treatment produced a better yield than no-treatment. Hence cow dung (organic manure) is recommended because of its easy availability, environmental and cost effectiveness.

\section{Acknowledgements}

We would like to express our gratitude to Dr. P.D. Sharma from Department of Plant Sciences, College of Agriculture, Arba Minch University for providing inorganic fertilizers which he procured from India.

\section{References}

[1] A.T. Ayoub. "Fertilizers and the Environment". Nutrient Cycling in Agroecosystems. 1999. Vol. 55: pp. 117-121.

[2] A. Mahajan, R.D. Gupta, and R. Sharma. "Bio-fertilizers-A way to sustainable agriculture". Agrobios Newsletter. 2008. Vol. 6: pp. 36-37.

[3] N. K. Fageria, V.C. Baligar, and Y. C. Li, "The role of nutrient efficient plants in improving crop yields in the twenty first century". Journal of Plant Nutrition. 2008. Vol. 31: pp. 11211157.

[4] E. A. E. Elsheikh. Environmental Soil Ecology, Khartoum University Press. 2011.

[5] T. Abera and D. Feyisa. Faba bean and field pea seed proportion for intercropping system in horro highlands of western Ethiopia. African Crop Science Journal. 2009. Vol. 16: pp. 243-249.

[6] W. G.O. Solomon, R.W. Ndana, and Y. Abdulrahim. The Comparative study of the effect of organic manure cow dung and inorganic fertilizer N.P.K on the growth rate of maize (Zea Mays L.). International Research Journal of Agricultural Science and Soil Science. 2012. Vol. 2: pp. 516-519.

[7] M. Berova G. Karanatsidis, K. Sapundzhieva, and V. Nikolova. Effect of organic fertilization on growth and yield of pepper plants (Capsicum annuиm L.). Folia Horticulturae Ann. 2010. Vol 22: pp. 3-7.

[8] J. Tanimu, E. O. Uyovbisere, S. W. J. Lyocks, and Y. Tanimu. Effects of Cow Dung on the Growth and Development of Maize Crop. Greener Journal of Agricultural Sciences. 2013. Vol. 3: pp. 371-383.

[9] C. Tu, J. B. Ristaino, S. Hu. Soil microbial bio-mass and activity in organic tomato farming systems: Effects of organic inputs and straw mulching. Soil Biology Biochemistry. 2006. Vol 38: pp. 247-255. 
[10] J. Mani. Early events in environmental stresses in plants: Induction mechanisms of oxidative stress. In: D. Inzè and M.V. Montague (eds.) Oxidative stress in plants. 2002. Taylor and Francis, New York. p. 217-246.

[11] B. S. Ewulo, S. O. Ojeniyi, and D. A. Akanni. Effect of poultry manure on selected soil physical and chemical properties, growth, yield and nutrient status of tomato. African J. Agriculture Research. (2008). Vol 3(9): pp. 612-616.

[12] Agnote. Fertilizer applications, Carol Rose, Extension Agronomist. NSW Department of Primary Industries, Kempsey DPI 496, Edited by Michel Dignand, Information Delivery Program, Wagga, USA. 2004.

[13] I. A. S. Gudugi. Effect of cow dung and variety on the growth and yield of Okra (Abelmoschus esculentus L.) European Journal of Experimental Biology. 2013. Vol 3(2): pp. 495-498.

[14] D. I. Arnon. Copper enzymes in isolated chloroplasts. Polyphenol oxidase in Beta vulgaris. Plant Physiology. 1949. Vol 24: pp. 1-15.

[15] U. K. Bansal, R. G. Saini, and A. Kaur. Genetic variability in leaf area and chlorophyll content of aromatic rice. International Rice Research Notes. 1999. Vol 24: pp. 21-28.

[16] O. H. Lowry, N. J. Rosenbrough, A. L. Farr, and R. J. Randall. Protein measurement with the Folin phenol reagent. Journal of Biological Chemistry. 1951. Vol 193: pp. 265-275.

[17] S. Moore, and W. H. Stein. Photometric ninhydrin method for use in the chromatography of amino acids. Journal of Biological Chemistry. 1948. Vol 76: pp. 367-388.

[18] A. J. Willis, and E. W. Yemm. The micro-estimation of sugars in plant tissues. New Phytologist. 1955 Vol. 54: pp. 20-22.

[19] P. Kumudha, and M. Gomathinayagam. Studies on the effect of biofertilizers on germination of Albizia lebbek (L.) Benth. seeds. Advanced Plant Science. 2007. Vol 20: pp. 417-421.

[20] M. Ram, R. Dawari, and N. Sharma. Direct, residual and cumulative effects of organic manures andbiofertilizers on yields, NPK uptake, grain yield and economics of wheat (Triticum aestivum L) under organic forming of rice-wheat cropping system. Journal of Organic Systems. 2014. Vol 9: pp. 16-30.

[21] R. Copper. Bacterial fertilizers in the Soviet Unions. Soil Fertility. 1979. Vol 22: pp. 327-333.

[22] M. Ram, R. Dawari, and N. Sharma. Effect of organic manures on basmati rice (Oryza sativa L.) under organic forming of rice-wheat cropping system. International Journal of Agricultural and crop sciences. 2011. Vol 3: pp. 76-84.

[23] C. R. Frink, P. E. Waggoner, and J.H. Ausubel. Nitrogen fertilizer: Retrospect and prospect. Proceedings of National Academy of Science. USA. 1999. Vol 96(4): pp. 1175-80.

[24] H. M. Zakir, M. N. Sultana, and K. C. Saha. Influence of Commercially Available Organic vs Inorganic Fertilizers on Growth Yield and Quality of Carrot. J. Environ. Science and Natural Resources. 2012. Vol 5(1): pp. $39-45$.

[25] K.A. Okeleye, and C.O. Alofe. Effect of nitrogen fertilizer source on dry matter accumulation and grain yields of open pollinatinated maize (Zea mays L.). Samaru Journal Agriculture Research. 1995. Vol 12: pp. 87-98.

[26] R. N. Sunanda, and K. Mallareddy. Effect of different organic manures and inorganic fertilizers on growth, yield and quality of carrot (Daucus carota L.). Karnataka Journal of Agricultural Sciences, 2007. Vol 20(3): pp. 686-688.

[27] B. Vijayakumari, R. Hiranmaiyadav, and M. Sowmya. A study on the effect of few eco-friendly manures on the growth attributes of carrot (Daucus carota L.). Journal of Environmental Science and Engineering. 2009. Vol 51(1): pp. 13-16.

[28] K. J. Rao, Ch. S. R. Lakshmi, and A.S. Raju. Evaluation of manurial value of urban and agricultural waste composts. Journal of Indian Society of Soil Science. 2008.254(3): pp. 295-299.

[29] I. Ahuja, and C.P. Mallik. Effect of Brassino steroida and Paleobutrazole on chlorophyll content in development of Brassic tuornefortii. Journal of Plant Science Research. 1977. Vol 13: pp. 31-34.

[30] A. R. Chopade, N. S. Naikwade, A. V. Nalawade, V. B. Shinde, and K.B. Burade. Effects of pesticides on chlorophyll content in leaves of medicinal plants. Pollination Research. 2007. Vol 26(3): pp. 491-494.

[31] S. Rajasekaran, P. Sundaramoorthy, and S. K. Ganesh. Effect of FYM, N, P fertilizers and biofertilizers on germination and growth of paddy (Oryza sativa. L). International Letters of Natural Sciences. 2015. Vol. 35: pp. 59-65.

[32] O.P. Singh, T. P. Singh, and A. L. Yadav. Variability and coheritability and estimates for agronomical and quality traits in Opium poppy (P. somniferum L.). Sci. Cult. 1999. Vol 64(34): pp. 107-109.

[33] C.K. Kokate, S.B. Golbale, and Purohit. Textbook of pharmacognosy. Nirali Prakashan. Pune. 1998. pp. 17-18.

[34] M. H. Ibrahim, H. Z. E. Jaafar, E. Karimi, and A. Ghasemzadeh. Impact of Organic and Inorganic Fertilizers Application on the Phytochemical and Antioxidant Activity of Kacip Fatimah (Labisia pumila Benth). Molecules. 2013. Vol 18: pp. 10973-10988. 